\title{
MENCEGAH STUNTING DALAM UPAYA MENGOPTIMALKAN PENGASUHAN SERIBU HARI PERTAMA KEHIDUPAN (HPK) DI MASA COVID-19 DESA PONDOKNONGKO KECAMATAN KABAT KABUPATEN BANYUWANGI
}

\author{
Ansari, Ina Rotul Ummah, \\ Tina Kustrianingsih,\& Rika Raudotul Jannah \\ Institut Agama Islam Ibrahimy Genteng Banyuwangi, Indonesia \\ ansaridosen1@gmail.com
}

\begin{abstract}
Stunting is a problem that occurs in infants who are chronically malnourished and results in slow growth and development of babies, so it takes care by giving the first 1000 days of life to the baby. Methods of socialization and education of stunting prevention by optimizing the provision of nutrient intake to families or mothers who have babies by providing nutritional intervention specifically to infants who have been programmed to children aged 0-12 months, and children's mothers 13-24 months, because it is the most effective preventive measure on belita. In terms of stunting prevention, there has been a lot of innovation and progress from the central government, local governments, and all sectors of society.
\end{abstract}

Keywords: Stunting, 1000 HPK, Covid-19. 


\section{Pendahuluan}

Indonesia dihadapkan pada beban ganda untuk meningkatkan dan mengupayakan menyelesaikan persoalan dan memberikan solusi yang baik terhadpa masyarakat terutama keluarga yang memiliki anak belita di bawah garis merah (kekurangan berat badan, ketertinggalan dalam pertumbuhan dan anemia) persoalan tersebut diakibatkan kurangnya nutrisi dan asupan suplemen.

Anak belata yang mempunyai gizi buruk diakibatkan kurangnya asupan nutrisi yang diberikan oleh keluarga, hal ini merupakan masalah secara global, dan bahkan di Indonesia nutrisi tidak dapat memuaskan masyarakat terutama ibu hamil dan kemudian melahirkan bayi yang bermasalah dengan kesehatannya. Masalah tersebut akan mempengaruhi belita yang baru dilahirkan dapat mengakibatkan terhambatnya pertumbuhan dan mengakibatkan bayi kurangnya gizi atau asupan.

Gizi buruk dapat menyebabkan keterlambatan perkembangan, terutama pada 1000 HPK. Dengan demikian untuk menghindari Stunting maka dengan cara memberikan pelayanan gizi dan pelayanan kesehatan yang baik terhadapat ibu hamil. Mengingat stunting akan mempengaruhi kecerdasan dan kesehatan anak di masa dewasa, maka 
upaya ini sangat diperlukan untuk memberikan solusi kekurangan gizi sehingga tidak bersifat permanin dan dapat memberikan kemudahan dan memberikan solusi yang terbaik.

Retardasi pertumbuhan merupakan faktor utama kurangnya pemberian gizi pada anak. Tidak ada penelitian yang menunjukkan bahwa genetika yang aktif untuk pengembangan fisik dan karakter tubuh terhadap anak belita. Secara umum, diyakini bahwa perkembangan fisik sepenuhnya dipengaruhi oleh genetika. ${ }^{1}$ Kesalahpahaman ini seringkali membuat sosialisasi stunting sulit dicegah, dan harus dilakukan upaya pemenuhan kebutuhan gizi anak sejak berada dalam kandungan sampai dengan umur 2 tahun. Adapun mensosialisasikan akan berlangsung secara rutin sehingga tetapi membutuhkan kesediaan masyarakat untuk menerimanya.

Menurut data BPS jumlah belita sebanyak 22.4 juta setiap tahun dan sedikitnya sebanyak 5.2 juta jiwa, ibu hami dan melahirkan belita adapun rata-rata bayi lahir setiap tahunnya sebanyak 4.9 juta jiwa. Sedangkan yang mengalami stunting bayi/belita di bawah usia 5 tahun yang mengalami stunting atau lebih pendek dari usia standar. Bukan

${ }^{1}$ SKM Merryana Adriani and Prof Dr M. S. Bambang Wirjatmadi, Gizi dan Kesehatan Balita: peranan mikero zinc pada pertumbuban balita (Jakarta: KENCANA Prenada Media Group, 2014), accessed September 9, 2021, http://lib.unair.ac.id.

Vol. 3 No. 2, Oktober 2021

Ansari, Dkk| 249 gurnal Pengabdian Masyarakat 
hanya perawakan pendek, reaksi berantai anak stunting lebih rumit. Selain masalah fisik dan perkembangan kognitif, anak kecil dengan keterlambatan perkembangan mungkin juga menghadapi masalah lain. Anak yang dikatagorikan stunting di lihat dari persoalannya dan bukan hanya perkembangan kognitif atau fisik, tetapi sistem metabolisme anak dengan keterlambatan perkembangan seringkali tidak ideal. Misalnya, jika anak lain dapat tumbuh, ia akan tumbuh secara horizontal. Inilah risiko yang dihadapi walaupun penyakit tersebut tidak menulara akan tetapi anak/belita yang ada di bawah garis merah akan mengakibatkan anak tersebut sulit untuk berkembang dan seringkali mereka sulit mencari pekerjaan karena keterbatasan kemampuan.

Pengasuhan 1000 hari sebelum kelahiran adalah preode sangat kritis bagi seorang anak untuk mempersiapakn dan meningkatkan kemampuan sehingga dapat berkembang secara alamiah pada umur 2 tahun. $^{2}$ Memperhatikan pemberian dan pengasuhan anak untuk memberikan gizi baik yaitu pada 1000 HPK dan akan mengarah pada tumbuh kembang anak yang optimal.

Desa Pondoknongko merupakan desa yang memiliki tiga dusun

2 “STUNTING DAN 1000 HPK - STIKES BANYUWANGI," n.d., accessed September 9, 2021, https://stikesbanyuwangi.ac.id/stunting-dan-1000-hpk/.

Vol. 3 No. 2, Oktober 2021

Ansari, Dkk| 250 Zurnal Pengabdian Masyarakat 
diantaranya, Dusun Krajan, Palukuning, dan Kedawung. Desa Pondoknongko masuk dalam wilayah pemerintahan Kecamatan Kabat Kabupaten Banyuwangi. Adapun jumlah penduduk Desa Pondoknongko sebanyak 3.522 jiwa yang tersebar ditiga (3) dusun yaitu Dusun Krajan, Dusun Palukuning, dan Dusun Kedawung. Jumlah Bumil (Ibu Hamil) di Desa Pondoknongko sebanyak 19 orang dengan rincian : Dusun Kedawung sebanyak 3 orang, Dusun Palukuning sebanyak 5 orang dan Dusun Krajan sebanyak 11 orang. Sementara jumlah balitanya sebanyak 276 dengan rincian : Dusun Kedawung sebanyak 75 balita, Dusun Palukuning sebanyak 80 balita dan Dusun Krajan sebanyak 121 balita. Desa Pondoknongko mempunyai 5 pos posyandu dimana tiap pos posyandu terdapat 2 balita kategori BGM. Rata-rata anak akan mengalami BGM (Balita Bawah Garis Merah) dikarenakan faktor ekonomi, kurangnya kecukupan gizi serta pola asuh orang tua.

Berdasarkan data dan uraian di atas penulis dapat memberikan sosialisasi untuk mengidukasi stunting kepada masyarakat dengan cara mencegah bagaimana untuk mengoptimalkan pengasuhan 1000 HPK Era Pandami Covid-19. 


\section{Metode}

Metode yang digunakan dalam kegiatan ini adalah:

\section{Tahap persiapan}

a. Survey atau menyelidiki dan mengamati lokasi yang akan dijadikan objek penelitian untuk memperkuat kegiatan pengabdian yang dapat diperlukan untuk mamajukan.

b. Rencana tersebut dapat dipantau dengan pergi langsung ke rumah anak kecil dan berkomunikasi dengan anggota keluarga untuk menentukan solusi atau pencegahan atas permaslahan tersebut.

c. Melaksanakan penelitian dana menjalin kerjasama serta berkomunikasi Alasan memilih dampingan dengan para pihak yaitu bidan, maupun kader posyandu

\section{Tahap demi tahap pelaksanaan}

a. Mensosialisasikan

Menyelenggarakan kegiatan melalui pendekatan secara khusus terhadapa keluarga terutama anak balita yang mengalami BGM (Balita Bawah Garis Merah) di Desa Pondoknongko dan bekerjasama dengan para pihak bidan, kader posyandu untuk mencipatakanm dan sosialisasi dan edukasi mengenai stunting dan cara pencegehannya. Kegiatan ini di arahkan untuk menyadarkan 
pentingnya mengoptimalkan pengasuhan anak di bawah umur atau anak belita bawah garis merah.

b. Pelatihan Pendampingan

1. Pelatihan, dilakukan terkait dengan bagaimana cara orangtua agar anak yang susah makan, mau makan dengan cara menyuguhkan makanan dengan varian menu yang berbeda. Misal mengolah ikan laut menjadi nugget dengan berbagai bentuk yang menarik bagi anak anak.

2. Mendampingi anak belita dan ibu hamil untuk memberikan dan mengenalkan makanan pendamping ASI, makanan yang mengandung vitamin, mengenalkan pada orangtua manfaat sayur dan buah bagi pertumbuhan dan perkembangan tubuh, dan yang tak kalah penting yaitu penanaman pola hidup sehat. Diantaranya berapa jam anak harus istirahat setiap harinya. Pentingnya kebersihan sanitasi juga harus diperhatikan.

c. Mengevaluasi

Dari awal, kita bisa melihat hasil dari pelaksanaan kegiatan atau prosedur dalam merealisasikan kegiatan pengabdian yang telah berlangsung yaitu pada tanggal 26 Juli s/d 31 Agustus 2021. Lokasi survey bertempat di Desa Pondoknongko Kecamatan Kabat 
Kabupaten Banyuwangi. Keberadaan peneliti dalam bidang ini bersifat terbuka sehingga dapat masukan maupun kritikan. Sedangkan data diperoleh melalui wawancara dan dokumentasi terhadap keluarga belita bawah garis merah dan kemudian dianalisis untuk memperoleh kesimpulan.

\section{Hasil dan Diskusi}

Stunting merupakan masalah kekurangan gizi kronis yang disebabkan oleh kekurangan asupan gizi dalam jangka panjang akibat ketidaksesuaian antara pola makan dan kebutuhan gizi. Status gizi adalah status kesehatan anak. Tuberkulosis ditentukan oleh kebutuhan tubuh akan energi dan zat gizi lain dari makanan.

Secara umum gizi mrupakan masalah dalam pertembuhan anak dengan pemberian gizi terhadap anak, maka anak dapat berkembang sesuai dengan apa yang diharapkan orang tua atau keluarga. ${ }^{3}$ Stunting menggambarkan keadaan malnutrisi kronis selama pertumbuhan dan perkembangan dalam beberapa tahun pertama kehidupan. Menurut standar pertumbuhan Organisasi Kesehatan Dunia, situasi ini dimanifestasikan oleh skor z tinggi badan spesifik (TB / U) di bawah 2

3 M. B. Arisman, "Buku Ajar Ilmu Gizi Edisi 2 - Gizi Dalam Daur Kehidupan" (EGC, 2009).

Vol. $3 \mathrm{No} .2$, Oktober 2021

Ansari, Dkk | 254 gurnal Pengabdian Masyarakat 
standar deviasi (SD).

Kekurangan gizi dapat menyebabkan stunting terutama 1000 HPK yaitu 270 hari selama kehamilan ditambah 365 hari pada tahun pertama, dan 365 hari tahun kedua. Seribu Hari adalah kesempatan sekali seumur hidup untuk membina anak-anak yang sehat dan cerdas. Salah satu cara untuk mencegah stunting adalah dengan memberikan pelayanan gizi dan kesehatan kepada ibu hamil. ${ }^{4}$

Stunting pada anak dapat mengganggu perkembangannya bahkan dapat meningkatkan risiko kematian anak. Efek jangka pendeknya adalah terhambatnya perkembangan anak, penurunan fungsi kognitif, penurunan fungsi imun, dan gangguan sistem pembakaran. Dalam jangka panjang, di masa dewasa, ada risiko penyakit degeneratif seperti diabetes, penyakit jantung koroner, hipertensi, dan obesitas. UNICEF, ${ }^{5}$ dalam laporannya ada Beberapa trik dan efeknya meliputi:

1. Sebelum 6 bulan, yaitu, 6 bulan yang lalu, anak-anak berpengalaman 6 bulan lalu serius sebelum usia dua tahun, akan mengalami hal-hal. Perkembangan sehat dan mental yang marah dengan anak-anak memiliki defisit jangka panjang, dan dapat memastikan bahwa

${ }^{4}$ Merryana Adriani and Bambang Wirjatmadi, Gizi dan Kesehatan Balita.

5 "FA_Preview_HSR_Book04.Pdf," n.d., accessed September 9, 2021, https://www. bappenas.go.id/files/1515/9339/2047/FA_Preview_HSR_Book04.pdf.

Vo1. $3 \mathrm{No} .2$, Oktober 2021

Ansari, Dkk| 255 Zurnal Pengabdian Masyarakat 
mereka tidak dapat dipelajari secara Dengan alasan inilah, pendampaing memilih pesantren miftahul ulum sebagai tempat yang bisa memfasilitasi pembedayaan santri. optimal di sekolah dibandingkan dengan anak-anak biasa.

2. Anak-anak berdasarkan trik cenderung menjadi sekolah yang tidak memiliki sekolah daripada anak-anak dengan kondisi gizi yang baik. Ini memberikan hasil keberhasilan anak-anak di masa depan mereka.

3. Dampak gizi pada anak usia dini yang dialami oleh trik dapat mencegah pertumbuhan dan kurangnya perkembangan kognitif. Anak-anak yang bekerja keras pada usia 5 cenderung menyelesaikan sepanjang hidup, dan kegagalan pertumbuhan anak usia dini berlanjut hingga remaja dan menanam wanita dewasa yang luar biasa dan secara langsung mempengaruhi kesehatan dan produktivitas, itu muncul kemungkinan BBLR. Karena kemungkinan akan dihambat selama proses pertumbuhan selama kelahiran, obrolan sangat berbahaya.

Diperkenalkan oleh Badan Kependudukan dan Keluarga Berencana $(\mathrm{BKKBN})$, stunting merupakan gangguan terhadap pertumbuhan anak yang diakibtkan kekurangan asupan gizi atau pengasuhan 1000 HPK. Keterlambatan perkembangan menyebabkan 
perkembangan dan pertumbuhan otak terhambat. Anak stunting cenderung lebih pendek dari anak rata-rata. Anak kecil dapat mengalami stunting karena beberapa alasan, ${ }^{6}$ antara lain :

1. Pemberian ASI yang tidak tepat dan metode pemberian makan yang buruk, serta metode pengasuhan yang tidak memuaskan.

2. Kebutuhan menyusui dan gizi ibu hamil dan ibu tidak mencukupi.

3. Tingginya angka kejadian penyakit menular terutama disebabkan oleh lingkungan tempat tinggal yang kotor dan pelayanan sanitasi yang tidak memadai.

Faktor-faktor ini dikombinasikan dengan rendahnya tingkat pendidikan, kemiskinan yang meluas, $^{7}$ dan meningkatnya pengangguran selama pandemi COVID-19. ${ }^{8}$ Keputusan Presiden

${ }^{6}$ Oktadila Nurjanah Lutfiana, "FAKTOR - FAKTOR YANG BERHUBUNGAN DEGAN KEJADIAN STUNTING DI WILAYAH KERJA UPT PUSKESMAS KELCOREJO KABUPATEN MADIUN TAHUN 2018," Other (STIKES Bhakti Husada Mulia Madiun, 2018), last modified 2018, accessed September 9, 2021, http://repository.stikes-bhm.ac.id/351/.

7 Kartika Pibriyanti, Suryono Suryono, and Cut Luthfi, "Faktor-Faktor Yang Berhubungan Dengan Kejadian Stunting Pada Balita Di Wilayah Kerja Puskesmas Slogohimo Kabupaten Wonogiri," Darussalam Nutrition Journal 3, no. 2 (November 10, 2019): 42-49, $\quad$ accessed $\quad$ September https://ejournal.unida.gontor.ac.id/index.php/nutrition/article/view/3398.

8 "Strategi Pengendalian Stunting di Era Pandemi - STIKES BANYUWANGI," n.d., accessed September 9, 2021, https://stikesbanyuwangi.ac.id/strategi-pengendalianstunting-di-era-pandemi/.

Vo 1. 3 No. 2, Oktober 2021

Ansari, Dkk | 257 Gurnal Pengabdian Masyarakat 
Nomor 42 Tahun 2013 tentang Gerakan Nasional (Gernas)9 tanggal 23 Mei 2013 menetapkan komitmen pemerintah untuk mempercepat perbaikan gizi. Dengan meningkatkan dan perhatian terhadap para pelaku untuk dikoordinasikan secara terprogram untuk meningkatkan pengasuhan dan pemberian asupan gizi terhadap belita dan kemudian dapat diprioritaskan untuk mempercepat perbaikan gizi masyarakat. Mengidentifikasi strategi utama Gernas untuk percepatan perbaikan gizi, yaitu:

1. Menciptakan sumber daya dan mengupayakan pembangunan arus utama dalam pembangunan ekonomi.

2. Membangkitkan kapasitas sumber daya manusia untuk menciptakan kompentensi dari segala sektor, baik pemerintah maupun swasta.

3. Meningkatkan dan memperkuat Inventasi yang berbasis data sehingga lebih efektif untuk meningkatkan pengetahuan masyarakat.

4. Mengupayakan masyarakat untuk berpartisipasi menerapkan nilainilai sosial yang terkandung didalam masyarakat sehingga dapat mendukung kesadaran gizi masyarakat.

9 "Kementerian PPN/Bappenas :: Gerakan Nasional Percepatan Perbaikan Gizi," accessed September 9, 2021, https://www.bappenas.go.id/id/profil-bappenas/unitkerja/deputi-sdm/dit-kgm/contents-direktorat-kesehatan-dan-gizi-masyarakat/gerakannasional-percepatan-perbaikan-gizi/.

Vol. $3 \mathrm{No} .2$, Oktober 2021

Ansari, Dkk| 258 gurnal Pengabdian Masyarakat 
Namun, mencegah stunting bukan hanya tanggung jawab pemerintah, tetapi juga semua pihak dan seluruh keluarga Indonesia. ${ }^{10}$ Dalam jangka panjang, stunting tidak hanya berdampak negatif pada pertumbuhan dan perkembangan anak, tetapi juga berdampak negatif pada perkembangan emosional dan menyebabkan kerugian ekonomi; hanya pada skala mikro dan makro dalam keluarga, dalam hal ini kesehatan nasional. anggaran pengeluaran. Upaya untuk mempercepat dan pemberian gizi perlu adanya komitmen bersama sehingga dapat dukungan dari berbagai pihak baik dari pemerintah pusat, provinsi, dan daerah serta dari lembaga-lembaga yang terkait sehingga dapat memberikan yang terbaik kepada masyarakat terutama terhadap keluarga yang mengalami belita di bawah garis merahdan dapat menumbuhkan keturunan yang sehat, produktif dan berdaya saing. Mulai dari memberikan nutrisi yang baik kepada 1.000 anak HPK, hingga menjaga kebersihan dan kesehatan lingkungan. Untuk mengatasi masalah gizi, ada dua solusi yang dapat ditempuh, yaitu intervensi spesifik dan sensitif. ${ }^{11}$

10 "Warta-Kesmas-Edisi-02-2018_1136.Pdf," n.d., accessed September 9, 2021, https://kesmas.kemkes.go.id/assets/upload/dir_519d41d8cd98f00/files/Warta-KesmasEdisi-02-2018_1136.pdf.

11 "Stunting: Pengertian, Dampak, Dan Cara Mencegahnya," accessed September 9, 
Salah satu intervensi yang sensitif adalah meningkatkan pengetahuan dan kapasitas orang tua atau keluarga tentang masalah gizi, serta kurangnya pengetahuan masyarakat tentang bahan makanan olahan (seperti ikan). Ada banyak ikan di sekitar mereka, tetapi mereka tidak memakannya. Karena kebanyakan dari mereka hanya bisa memasak ikan dengan cara digoreng dan dibakar, anak-anak akan lebih cepat bosan dengan menu ikan.

Kegiatan intervensi spesifik yang dilakukan oleh Kementerian Kesehatan dalam penanggulangan masalah gizi,12 antara lain:

1. Memberikan suplemen darah untuk remaja putri, calon pacar dan ibu hamil

2. Promosikan ASI eksklusif

3. Promosikan makanan pendamping ASI

4. Promosikan makanan yang diperkaya seperti garam beryodium

5. Promosi dan Latihan Buxue

6. 6 Tablet Suplementasi Zat Gizi Mikro (Taburia)

2021, https://kesehatan.kontan.co.id/news/stunting-pengertian-dampak-dan-caramencegahnya? page $=$ all.

12 "Intervensi Stunting Terintegrasi Awal Wujudkan Indonesia Bebas Stunting," Sehat Negeriku, February 14, 2018, accessed September 9, 2021, https://sehatnegeriku.kemkes.go.id /baca/umum/20180214/0424919/intervensi-stuntingterintegrasi-awal-wujudkan-indonesia-bebas-stunting/.

Vol. 3 No. 2, Oktober 2021

Ansari, Dkk | 260 Zurnal Pengabdian Masyarakat 


\section{Suplementasi Nutrisi Makro (PMT)}

8. Kelas Bersalin

9. Promosi dan Latihan Gizi Seimbang dan Perubahan Perilaku 10.Obat cacing

Dalam penanganan stunting dikenal lima pilar, ${ }^{13}$ yaitu: Pilar 1: Komitmen dan visi pemimpin negara Pilar 2: Gerakan nasional fokus pada pemahaman, perubahan perilaku, komitmen politik dan akuntabilitas Pilar 3: Integrasi dan koordinasi Dan mengkonsolidasikan rencana nasional, regional dan regional dan masyarakat Pilar 4: Mempromosikan kebijakan gizi dan ketahanan pangan. Pilar 5: Pemantauan dan evaluasi lima pilar pertumbuhan manajemen yang tertinggal dicapai melalui intervensi spesifik dan sensitif di sektor kesehatan. tercapainya tujuan yaitu perkembangan anak yang maksimal (dengan kemampuan mempersiapkan diri secara emosional, sosial dan fisik untuk belajar, berinovasi dan berkompetisi)

Di Dusun Krajan Desa Pondoknongko, kami melakukan kegiatan pencegahan stunting dengan mengoptimalkan 1000 hari sebelum kelahiran (HPK), membekali ibu hamil, ibu menyusui, dan ibu balita dengan pengetahuan dan wawasan tentang pentingnya keterlambatan

13 "Warta-Kesmas-Edisi-02-2018_1136.Pdf."

Vo1. 3 No. 2, Oktober 2021

Ansari, Dkk| 261 Zurnal Pengabdian Masyarakat 
tumbuh kembang. 1000 hari pertama kehidupan (HPK). Kegiatan ini kami awali dengan membantu keluarga yang memiliki anak balita yang tumbuh kembangnya berada di bawah garis merah (BGM). Sosialisasi dan edukasi ini bertujuan untuk meningkatkan pengetahuan ibu usia subur, ibu hamil (bumil) dan ibu menyusui (busui) tentang pentingnya pencegahan stunting bagi tumbuh kembang anak.

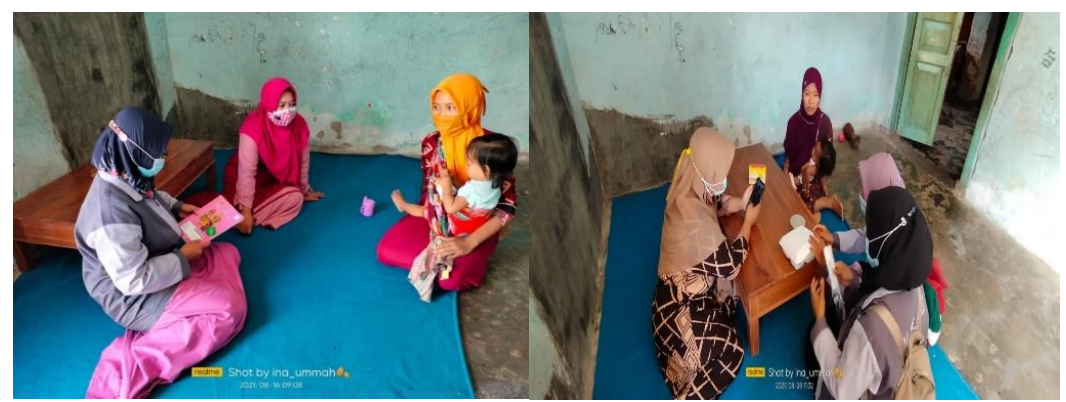

Gambar 1. Pendampingan Keluarga Balita Bawah Garis Merah (BGM)

Pelaksanaan kegiatan sosialisasi dan edukasi tentang stunting dilaksanakan pada hari Kamis, 19 Agustus 2021 pukul 09.00 WIB di Balai Desa Pondoknongko Kecamatan Kabat Kabupaten Banyuwangi. Kegiatan ini kami laksanakan sesuai dengan aturan higiene. Tahapan pelaksanaan kegiatan antara lain: 1. Tes suhu tubuh 2. Pemberian hand sanitizer 3. Pengisian daftar hadir 4. Pembukaan 5. Pemberian materi 6. Diskusi/Tanya Jawab 5. Berakhir sesuai kesepakatan memenuhi protokol kesehatan. Sebelum terjadinya sosialisasi dan edukasi, 
masyarakat hanya mengetahui kata stunting tentang pengetahuan masyarakat tentang stunting, dan tidak mengetahui cara pencegahan stunting pada anak, dan banyak masyarakat yang tidak mengetahui pentingnya 1.000 hari pertama kehidupan. Mencegah dampak stunting dan stunting Malnutrisi pada anak usia dini akan berlangsung sepanjang siklus hidup manusia.

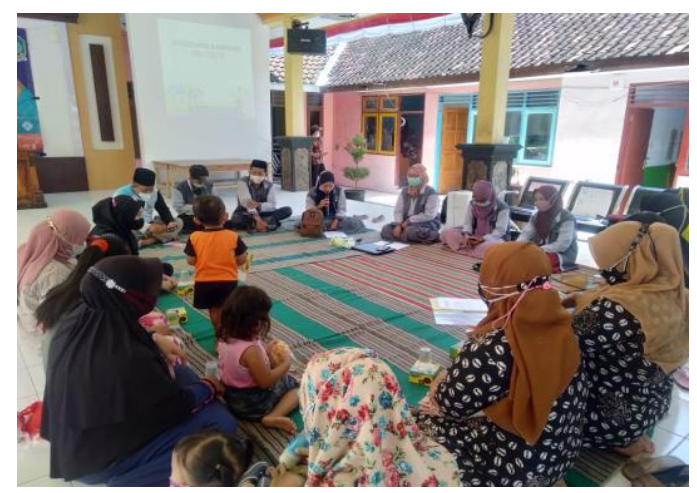

Gambar 2. Sosialisasi dan edukasi stunting pada masyarakat

Setelah sosialisasi dan edukasi diskusi, pertama 1000 hari kehidupan (HPK) dari kehidupan yang lebih baik memahami pentingnya paling mengejutkan dari seorang wanita hamil yang lebih baik, dan 6 bulan menyusui kebutuhan untuk mencapai, nafsu makan gizi dari 5 Anak yang sehat 5 Anak, sempurna untuk anak-anak untuk anak-anak dari 6 bulan hingga 2 tahun, dan mendorong kreativitas ibu. 
Kegiatan sosialisasi dan pendidikan adalah partai politik, wanita hamil, orang tua dari ibu bayi, orang tua masa kecil, eksekutif Posyandu dan TP PKK Desa Pondoknongko. Apa yang terjadi dengan anak-anak sinkronisasi sensitif ini akan menjadi dasar pertumbuhan dan perkembangan anak-anak pada tahap selanjutnya.

Sosialisasi dan pendidikan ini telah berhasil mencapai tujuan utama, yaitu, peningkatan generasi yang sehat dan produktif di masa depan, dan memiliki daya saing. Dimulai dengan nutrisi yang baik untuk anak-anak dengan 1000 HPK sampai mereka menjaga lingkungan mereka bersih dan sehat.

\section{Kesimpulan}

Hasil dari edukasi masyarakat tentang pentinya mengoptimalkan stunting, dapat ditarik kesimpulan sebagai berikut:

Fokus sosialisasi dan edukasi stunting ini adalah bagaimana mencegah stunting, pentingnya 1000 HPK bagi ibu-ibu hami, ibu-ibu menyusui, dan ibu belita. Masa 1000 hari pertama kehidupan pemberian asupan berupa gizi dan nutrisi pada (280 hari selama kehamilan, dan 720 hari setelah bayir dilahirkan) Masa ini merupakan masa yang menentukan kualitas hidup, dan dapat dibuktikan secara ilmiah bahwa masa itulah yang menentukan kualitas hidup. Bidan desa dan kader posyandu 
mempunyai tugas penting yaitu mengenalkan dan melahirkan 1000 hari pertama kehidupan (HPK) melalui berbagai kegiatan sosialisasi di masyarakat untuk melaksanakan program yang telah berjalan sesuai dengan situasinya terutama terhadap ibu rumah tangga yang memiliki anak menyusui dan atau ibuu yang memiliki anak yang berusia 1-2 tahun.

\section{Daftar Pustaka}

Arisman, M. B. “Buku Ajar Ilmu Gizi Edisi 2 - Gizi Dalam Daur Kehidupan." EGC, 2009.

Lutfiana, Oktadila Nurjanah. "FAKTOR - FAKTOR YANG BERHUBUNGAN DEGAN KEJADIAN STUNTING DI WILAYAH KERJA UPT PUSKESMAS KELCOREJO KABUPATEN MADIUN TAHUN 2018." Other. STIKES Bhakti Husada Mulia Madiun, 2018. Last modified 2018. Accessed September 9, 2021. http://repository.stikes-bhm.ac.id/351/.

Merryana Adriani, SKM, and Prof Dr M. S. Bambang Wirjatmadi. Gizi dan Kesehatan Balita: peranan mikro zinc pada pertumbuhan balita. Jakarta: KENCANA Prenada Media Group, 2014. Accessed September 9, 2021. http://lib.unair.ac.id.

Pibriyanti, Kartika, Suryono Suryono, and Cut Luthfi. “Faktor-Faktor 
Yang Berhubungan Dengan Kejadian Stunting Pada Balita Di Wilayah Kerja Puskesmas Slogohimo Kabupaten Wonogiri." Darussalam Nutrition Journal 3, no. 2 (November 10, 2019): 42-49. $\begin{array}{lll}\text { Accessed September } & \text { 9, }\end{array}$ https://ejournal.unida.gontor.ac.id/index.php/nutrition/article/vie $\mathrm{w} / 3398$.

“FA_Preview_HSR_Book04.Pdf," n.d. Accessed September 9, 2021. https://www.bappenas.go.id/files/1515/9339/2047/FA_Preview_HS R_Book04.pdf.

“Intervensi Stunting Terintegrasi Awal Wujudkan Indonesia Bebas Stunting." Sehat Negeriku, February 14, 2018. Accessed September 9, 2021.

https://sehatnegeriku.kemkes.go.id/baca/umum/20180214/0424919/inter vensi-stunting-terintegrasi-awal-wujudkan-indonesia-bebasstunting/.

“Kementerian PPN/Bappenas :: Gerakan Nasional Percepatan Perbaikan Gizi." Accessed September 9, 2021. https://www.bappenas.go.id/id/profil-bappenas/unit-kerja/deputisdm/dit-kgm/contents-direktorat-kesehatan-dan-gizimasyarakat/gerakan-nasional-percepatan-perbaikan-gizi/. 
"Strategi Pengendalian Stunting di Era Pandemi - STIKES BANYUWANGI," n.d. Accessed September 9, 2021. https://stikesbanyuwangi.ac.id/strategi-pengendalian-stunting-diera-pandemi/.

“STUNTING DAN 1000 HPK - STIKES BANYUWANGI,” n.d. Accessed September 9, 2021. https://stikesbanyuwangi.ac.id/stunting-dan1000-hpk/.

"Stunting: Pengertian, Dampak, Dan Cara Mencegahnya." Accessed September 9, 2021. https://kesehatan.kontan.co.id/news/stuntingpengertian-dampak-dan-cara-mencegahnya?page=all .

“Warta-Kesmas-Edisi-02-2018_1136.Pdf," n.d. Accessed September 9, 2021.

https://kesmas.kemkes.go.id/assets/upload/dir_519d41d8cd98f00/files/W arta-Kesmas-Edisi-02-2018_1136.pdf. 


\section{JURNAL}

\section{As-Sidanah}

Vol. 03 No. 2, Oktober 2021 